\title{
The effects of docking on performance and carcass characteristics of male Karakaş lambs
}

\author{
Ö. Gökdal ${ }^{1, \#}$, T. Aygün ${ }^{2}$, M. Bingöl ${ }^{2}$ and F. Karakuș ${ }^{2}$ \\ ${ }^{1}$ Adnan Menderes Üniversitesi, Çine Meslek Yüksekokulu, 09500, Çine, Aydın, Turkey \\ ${ }^{2}$ Yüzüncü Y1l Üniversitesi, Ziraat Fakültesi Zootekni Bölümü, 65080, Van, Turkey
}

\begin{abstract}
The effects of tail docking at birth on growth performance and carcass characteristics of fat-tailed male Karakaş lambs were investigated. A total of 23 Karakaş single-born male lambs was used in this study. Nine were docked at one day of age using rubber elastrator rings and the rest was left intact. After weaning, the lambs were fed a finishing diet for 70 days, and then slaughtered to evaluate carcass characteristics. Total weight gains during the finishing period were $14.3 \pm 1.00$ and $18.9 \pm 0.82 \mathrm{~kg}$ and average daily live weight gains $204.7 \pm 14.41$ and $269.9 \pm 11.72 \mathrm{~g}$ for the undocked $v s$. the docked group, respectively. The carcasses of the docked group contained more kidney, pelvic and internal fat than the intact lambs as well as a higher percentage of subcutaneous and intramuscular fat. The weights of the different carcass cuts of the docked lambs were also heavier that those of the intact group. The results indicated that the tail docking of fat-tailed Karakass lambs at birth improved weight gain and desirable carcass characteristics compared to those of undocked lambs.
\end{abstract}

Keywords: Karakaş lambs, fat tail docking, growth performances, slaughter

${ }^{\#}$ Corresponding author. E-mail: ogokdal@yahoo.com

\section{Introduction}

Meat production from sheep has retained its importance for centuries in the economy as well as its role in human nutrition in Turkey. Mutton makes an important contribution to red meat production, amounting to $26 \%$ of the total meat production in Turkey (Anon, 2000). However, the present meat production performances of native sheep breeds are far from optimal. The traditional extensive production methods, poor environmental conditions, economic limitations, lack of organisations among producers and genotypic characteristics of sheep are restrictive factors for optimum production. Native breeds comprise $96 \%$ of the sheep population of the country, whereas pure Merino and its crosses comprise only 4\%. Approximately $87 \%$ of the sheep population in Turkey consists of fat-tailed breeds.

The fat-tailed Karakaş sheep, a subtype of the Akkaraman sheep breed, is favourably characterised by its adaptation to harsh environmental and feeding conditions. The Karakaş sheep are found in the Van and Bitlis provinces of Eastern Anatolia in Turkey. The Karakaş sheep are also well known to tolerate extreme temperatures, poor feeding conditions and diseases. A characteristic of Karakaş sheep is a white body coat with dark (generally black) stains around the eyes and mouth. Traditional breeders normally rear this type of sheep, which graze mostly in the outskirts of the villages, on stubble, on canal banks and by the roadside. Adult body weight in females ranges from 46.4 to $53.0 \mathrm{~kg}$ (Karaca et al., 1996; Gökdal, 1998; Gökdal et al., 2000). Growth, fattening and carcass characteristics of Karakaş lambs under semi-intensive and rural farm conditions were studied by Karaca et al. (1991), Demirulus \& Karaca (1994), Aygün et al. (1998), Gökdal (1998), Gökdal et al. (1999), Cengiz et al. (2002) and Ülker et al. (2002). The fat-tailed Karakaş sheep is characterised by a low growth rate and poor carcass characteristics under intensive feedlot conditions (Aygün et al., 1998; Cengiz et al., 2002). Cengiz et al. (2002) reported that the average daily gain of male Karakaş lambs under intensive feedlot conditions for 70 days was $0.197 \mathrm{~kg}$. Aygün et al. (1998) and Cengiz et al. (2002) reported that consumers do not find the meat of Karakaş lambs delicious because of the fat distribution in the body. Information on the effects of docking on fattening performance and carcass characteristics of fat-tailed Akkaraman and Karakaş sheep is scarce. Such information is essential to evaluate production characteristics and improve fattening performance and carcass characteristics of fat-tailed native sheep breeds of Turkey.

The major biological role of fat is undoubtedly to serve as an energy store, providing a survival buffer against periodic food scarcity such as in drought and winter (Negussie et al., 2003). Fat is the most variable tissue in the carcass and varies not only in total amount but also in its distribution between the 
various deposits which alter markedly during growth (Negussie et al., 2003). The fat deposited in the tail is considered as an energy source for the fat-tailed sheep during the times of low energy intake (O'Donovan $e t$ al., 1973; Biylkoğlu et al., 1977). However, the fat tail of the breed is considered a liability in terms of reproduction, growth and feedlot performance and carcass marketing conditions. In addition, the fat deposition in the body or tail requires more energy than the deposition of lean tissue. Cengiz \& Arik (1994) reported that in fat-tailed sheep breeds, the effect of docking on conversion rate of concentrates into meat tissue was more efficient than into fat tissue.

Numerous breeds of sheep and a diversity of production systems produce a wide variety of carcasses to satisfy different consumer requirements on the international market. For commercial reasons and because of consumer demand there is a need to reduce the tail fat part of fat-tailed sheep carcasses in Turkey. Consumers prefer fatter meat where the fat is distributed between the meat fibres. In addition, it is becoming more difficult to market excessively large tailed carcasses. The carcasses of fat-tailed sheep breeds are marketed with intact fat tails in Turkey. The presence of fat tails lowers the desirability of the carcass to the consumer and consequently the commercial value of the carcass. In addition, the consumer prefers fat dispersed throughout the meat fibres rather than as tail fat. Therefore, for consumers in Turkey, tail docking is one of the methods of producing delicious and desirable carcass from fat-tailed breeds. The practice of docking lambs by various methods is used in order to obtain preferred products. Tails are removed using a knife, rubber elastrator ring or the hot tail docking iron. Peers et al. (2002) reported that docking of lambs by rubber elastrator rings was associated with less pain than other methods.

The objectives of docking fat tails in lambs are to improve meat quality, increase feed efficiency, improve live weight gain and to facilitate natural mating with non-fat-tailed breeds (Gürsoy \& Özcan, 1982; Cengiz \& Arık, 1994; Karakuş \& Cengiz, 2001; Pollard et al., 2001). Although the studies referring to the docking of lambs of the fat-tailed sheep breeds showed various effects on the growth rate, carcass characteristics and fat deposition over the body, the majority found that docking of lambs improves the live weight gain in fattening, feed efficiency and carcass characteristics (Gürsoy \& Ö̈zcan, 1982; Cengiz \& Arık, 1994; Karakuş \& Cengiz, 2001; Bingöl et al., 2002).

The objective of the study was to evaluate the effects of docking on finishing performance and carcass characteristics of fat-tailed male Karakaş lambs.

\section{Materials and Methods}

A total of 23 fat-tailed Karakaş single-born male lambs was used in the study. They were raised at the Research and Practice Farm, Department of Animal Science, Yüzüncü Y1l University, Van, Turkey. Male Karakaş lambs, born within a period of one week, were randomly assigned to two groups: docked $(n=9)$ and intact (control) $(\mathrm{n}=14)$ lambs. The lambs in the "docked" group were docked at one day of age using rubber elastrator rings. The tails were removed after two weeks. All lambs were weaned at two months of age and placed on a finishing diet.

At the beginning of the finishing period, the live weights of all lambs (body weight at three consecutive days after weaning) were recorded. The animals were housed in groups according to treatment and were fed a concentrate mixture ad libitum and $100 \mathrm{~g}$ clover hay/animal/day. The concentrate contained $90 \%$ dry matter and $168 \mathrm{~g}$ crude protein, $88.8 \mathrm{~g}$ crude ash and $98 \mathrm{~g}$ crude fat $/ \mathrm{kg}$ feed. The hay contained $91.2 \%$ dry matter and $139 \mathrm{~g}$ crude protein and $375 \mathrm{~g}$ crude fibre $/ \mathrm{kg}$. The finishing period lasted for 70 days after which the lambs were slaughtered. Live weights of all animals were recorded every second week. Final weights of all animals were recorded at three consecutive days after $12 \mathrm{~h}$ fasting and then after $24 \mathrm{~h}$ fasting prior to slaughter (Cengiz et al., 1989; Eliçin et al., 1989; Ertuğrul et al., 1989). Concentrate consumption of the groups was recorded.

After complete eviceration and dressing, carcasses were weighed warm and again after being chilled for $24 \mathrm{~h}$ at $+4{ }^{\circ} \mathrm{C}$. The head, skin, feet, genitalia and offal were weighed. Internal fat deposited around the kidneys (perinephric fat) and around the gastrointestinal tract (gut fat) was dissected and weighed. The tail was removed at its articulation and the cannon bones were dissected from the carcass. The cold carcass was split along the backbone and carcass length, leg depth, leg width, leg length, rump width, chest depth, chest width and shoulder width were measured on the whole and left half of a carcass. The left half of the carcass was divided into six parts, according to the procedure of Colomer-Rocher et al. (1987) and weighed. The surface area of a cross section of the M. longissimus thoracis between the $12^{\text {th }}$ and $13^{\text {th }}$ rib was measured by tracing it onto acetate paper and measuring the area using a planimeter. Dressing percentage was calculated as a ratio of $24 \mathrm{~h}$ fasting weight prior to slaughter and cold carcass weight. Proportional weights were 
calculated as the ratio of the heart, lungs and liver weights relative to slaughter weight. The proportional weights of the testes and internal fat were calculated relative to warm carcass weight and those of the other organs and carcass cuts relative to the cold carcass weight, according to the procedure of Cengiz et al. (1989). The proportion of the muscle, bone and fat in the carcass was estimated by physical dissection and weighing of these tissues in the rib area between the $6^{\text {th }}$ and $12^{\text {th }}$ rib (More-O'Ferrall \& Timon, 1977).

The mathematical model included fixed effect due to group and random effect due to residual error (SAS, 1988). The growth performance, live weight and various carcass characteristics were assessed. The Student's t-test was used to detect significant differences between means. Daily feed consumption and feed conversion efficiency were calculated on a group basis.

\section{Results and Discussion} 1.

Growth performances during the finishing period of the intact and docked lambs are given in Figure

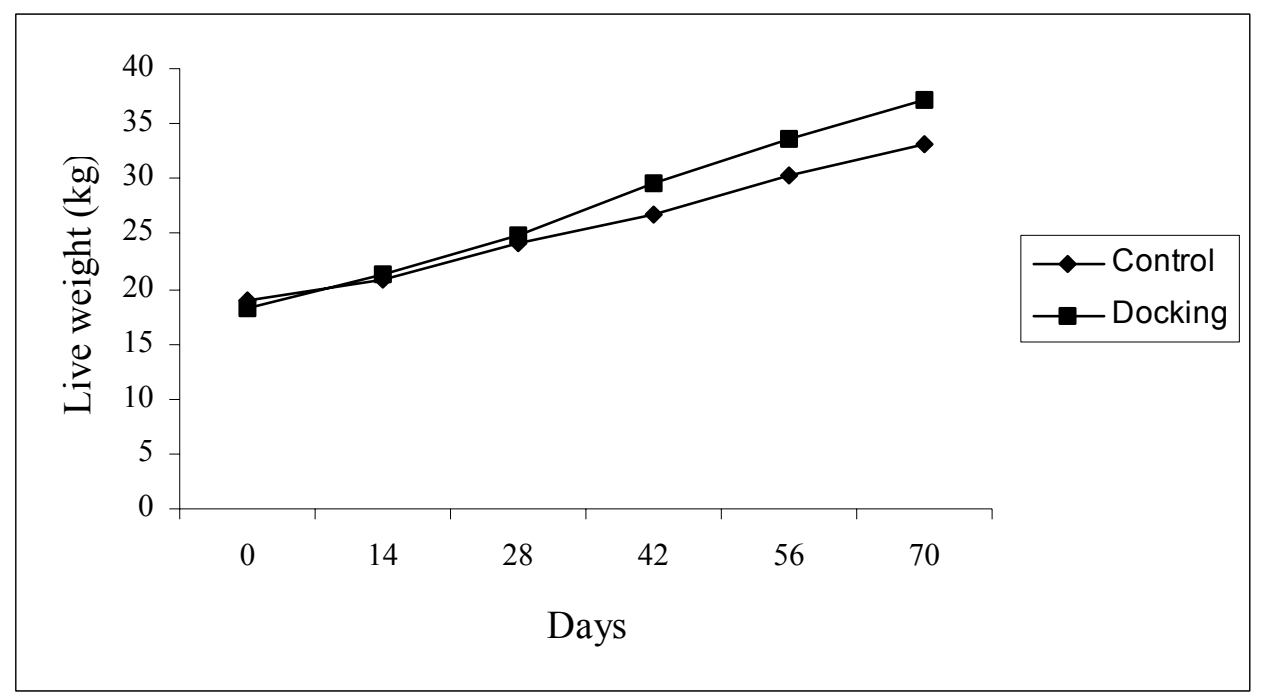

Figure 1 Live weights of control and docked Karakaş lambs at various stages of the finishing period

The docked lambs had higher growth rates than the intact animals (Figure 1). Growth performance and mean feed consumption of groups during the finishing period are presented in Table 1. Total and daily weight gains during the finishing period were higher $(\mathrm{P}<0.01)$ in docked lambs compared to control lambs. Similarly, the final live weights of docked animals at the end of the finishing period tended to be higher than that of the control animals $(\mathrm{P}>0.05)$. These findings are consistent with those of Cengiz \& Arı (1994) who found that the final weights and total and daily weight gains in docked lambs were higher than intact lambs. However, Alkass et al. (1985) and Marai et al. (1987) found no differences in growth performance between undocked and docked Awassi and Ossimi male lambs, respectively.

Table 1 Mean ( \pm s.e.) weight gain and feed consumption of intact and docked Karakaş lambs during the finishing period on a high concentrate diet

\begin{tabular}{lcc}
\hline & \multicolumn{2}{c}{ Groups } \\
\cline { 2 - 3 } Trait & Control lambs & Docked lambs \\
\hline Initial weight $(\mathrm{kg})$ & $18.9 \pm 0.92$ & $18.3 \pm 1.17$ \\
Final weight $(\mathrm{kg})$ & $33.2 \pm 1.59$ & $37.2 \pm 1.59$ \\
Total weight gain in finishing $(\mathrm{kg})$ & $14.3 \pm 1.00^{* *}$ & $18.9 \pm 0.82^{* *}$ \\
Daily weight gain $(\mathrm{g})$ & $204.7 \pm 14.41^{* *}$ & $269.9 \pm 11.72^{* *}$ \\
Daily feed consumption $(\mathrm{kg})$ & 0.88 & 1.23 \\
Feed conversion efficiency & 4.31 & 4.55 \\
\hline
\end{tabular}

$* *$ Within rows differences were statistically significant at $\mathrm{P}<0.01$ 
Feed conversion efficiency (the concentrate consumption per kilogram live weight gain) and daily concentrate consumption of the two groups were similar. Other studies with different sheep breeds found that docking did not affect feed efficiency (Gürsoy \& Özcan, 1982; Biçer, 1988; Cengiz \& Arık, 1994).

Carcass measurements of the two groups of lambs are presented in Table 2. Except for chest width and rump width, there were no differences in carcass measurements between the two groups. The values of chest width and rump width were higher in the docked than in the control lambs $(\mathrm{P}<0.01$ and $\mathrm{P}<0.05$, respectively). An indirect increase in carcass measurements in response to docking has been reported previously (Bıyıkoğlu et al., 1977; Cengiz \& Arık, 1994). However, the effect of docking on carcass measurements is not well documented. In general, all carcass measurements of docked animals tended to be higher than those of the intact lambs, with the exception of the cross section of the M. longissimus thoracis, though the means of the groups did not differ $(\mathrm{P}>0.05)$. In contrast, it has been reported in studies on other fat-tailed sheep breeds that the M. longissimus dorsi area was positively affected by docking (Marai et al., 1987; Biçer, 1988; Gürsoy et al., 1992; Cengiz \& Arık, 1994). In the current study there were no differences $(\mathrm{P}>0.05)$ in fat thickness over the M. longissimus thoracis area (Table 2).

Table 2 Mean ( \pm s.e.) slaughter and carcass characteristics in intact $v s$. docked Karakaş lambs

\begin{tabular}{|c|c|c|}
\hline \multirow[t]{2}{*}{ Trait } & \multicolumn{2}{|c|}{ Groups } \\
\hline & Control lambs & Docked lambs \\
\hline \multicolumn{3}{|l|}{ Carcass measurements (cm) } \\
\hline Chest depth & $24.9 \pm 0.48$ & $26.0 \pm 0.31$ \\
\hline Leg depth & $8.7 \pm 0.33$ & $8.8 \pm 0.12$ \\
\hline Chest width & $16.5 \pm 0.48^{* *}$ & $18.9 \pm 0.72 * *$ \\
\hline Shoulder width & $15.8 \pm 0.67$ & $16.2 \pm 0.37$ \\
\hline Rump width & $18.0 \pm 0.48^{*}$ & $19.2 \pm 0.26^{*}$ \\
\hline Leg width & $6.3 \pm 0.21$ & $6.4 \pm 0.19$ \\
\hline Leg length & $28.9 \pm 0.28$ & $28.8 \pm 0.47$ \\
\hline Carcass length & $54.9 \pm 1.06$ & $55.6 \pm 0.62$ \\
\hline M. longissimus thoracis area $\left(\mathrm{cm}^{2}\right)$ & $19.3 \pm 1.08$ & $18.6 \pm 0.90$ \\
\hline Fat thickness over LD (mm) & $2.1 \pm 0.21$ & $2.7 \pm 0.41$ \\
\hline \multicolumn{3}{|c|}{ Carcass weight (kg) and dressing percentage (\%) } \\
\hline Slaughter weight & $31.9 \pm 1.87$ & $36.5 \pm 1.66$ \\
\hline Warm carcass weight & $15.2 \pm 1.04$ & $17.5 \pm 0.92$ \\
\hline Cold carcass weight & $14.9 \pm 1.04$ & $17.1 \pm 0.92$ \\
\hline Untailed cold carcass weight & $12.7 \pm 0.80^{* *}$ & $16.1 \pm 0.80^{* *}$ \\
\hline Dressing percentage & $46.2 \pm 0.71$ & $46.8 \pm 0.49$ \\
\hline Untailed dressing percentage & $39.8 \pm 0.52 * *$ & $43.9 \pm 0.31 * *$ \\
\hline \multicolumn{3}{|l|}{ Offal items $(\mathrm{kg})$} \\
\hline Head weight & $1.84 \pm 0.08$ & $2.0 \pm 0.09$ \\
\hline 4 feet weight & $0.80 \pm 0.03$ & $0.75 \pm 0.06$ \\
\hline Skin weight & $3.79 \pm 0.29$ & $4.09 \pm 0.19$ \\
\hline Heart, lungs and liver weight & $1.39 \pm 0.07^{*}$ & $1.58 \pm 0.04^{*}$ \\
\hline Testes weight & $0.10 \pm 0.01$ & $0.12 \pm 0.01$ \\
\hline Kidney weight & $0.10 \pm 0.00$ & $0.11 \pm 0.00$ \\
\hline Spleen weight & $0.06 \pm 0.00$ & $0.06 \pm 0.00$ \\
\hline Kidney and pelvic fat weight & $0.06 \pm 0.00^{* *}$ & $0.15 \pm 0.02 * *$ \\
\hline Internal fat weight & $0.04 \pm 0.00^{* *}$ & $0.14 \pm 0.02 * *$ \\
\hline Tail weight & $2.12 \pm 0.27^{* *}$ & $1.07 \pm 0.13 * *$ \\
\hline \multicolumn{3}{|c|}{ Wholesale cuts of left half of carcass (kg) } \\
\hline Leg weight & $2.21 \pm 0.13^{* *}$ & $2.72 \pm 0.11 * *$ \\
\hline Back-loin weight & $1.15 \pm 0.08 * *$ & $1.53 \pm 0.08^{* *}$ \\
\hline Forearm weight & $1.22 \pm 0.07^{*}$ & $1.43 \pm 0.06^{*}$ \\
\hline Shoulder weight & $0.41 \pm 0.02$ & $0.49 \pm 0.03$ \\
\hline Neck weight & $0.54 \pm 0.03^{* *}$ & $0.67 \pm 0.03 * *$ \\
\hline Flank-chest weight & $0.75 \pm 0.06^{* *}$ & $1.15 \pm 0.07 * *$ \\
\hline
\end{tabular}

*Within rows differences were statistically significant at $\mathrm{P}<0.05$

$* *$ Within rows differences were statistically significant at $\mathrm{P}<0.01$ 
Slaughter and carcass characteristics of the two groups of lambs are presented in Table 2. Slaughter weight, warm carcass weight, cold carcass weight and dressing percentage of docked lambs tended to be higher than in the control lambs, although the differences were not significant $(\mathrm{P}>0.05)$. Marai et al. (1987) reported significant increases in slaughter weight, carcass weight and dressing percentage in docked compared to their intact control lambs. The untailed cold carcass weight of the docked group was higher $(\mathrm{P}<$ 0.01) than that of the intact lambs, in agreement with the findings of Cengiz \& Arrk (1994). The untailed dressing percentages of docked lambs were higher than those of the control lambs $(\mathrm{P}<0.01)$. These results are in agreement with those of Cengiz \& Ark (1994) and Bingöl et al. (2002) who found that docking reduced the proportion of tail fat significantly and increased the market prices of the carcass compared to intact fat-tail lambs. The reason for the high untailed dressing percentage of docked lambs seems to be that more fat was distributed between meat fibres in this group than in the fat tailed group. This is desirable from the point of view of consumers' demand and thus for commercial reason.

In the present study docking did not have any effect $(\mathrm{P}>0.05)$ on the weights of the heads, four feet, skins, testes, kidneys and spleens of the lambs. However, heart, lungs and liver weights were higher $(\mathrm{P}<$ 0.05) in the docked than in the control lambs (Table 2). Similar results have been reported by Akkaraman (Cengiz \& Arık, 1994) and Norduz lambs (Bingöl et al., 2002). The carcasses of the docked lambs had more $(\mathrm{P}<0.01)$ kidney, pelvic and internal fat than those of the control lambs. However, tail weights were higher $(\mathrm{P}<0.01)$ in control lambs than in docked lambs, and the amount of kidney, pelvic and internal fat in the docked lambs was too low to affect carcass yield compared to the weight of the tail fat.

The wholesale cuts of the left half of the carcasses are presented in Table 2. The leg weight, backloin weights, neck weight, flank-chest weights $(\mathrm{P}<0.01)$, forearm weight $(\mathrm{P}<0.05)$ were higher in docked than in the control group. The higher body and carcass weights were the indirect result of docking, due to higher growth rates in this group than in the control group. It has been reported that docking of fat-tails increased the weights of valuable wholesale cuts in the carcass of fat-tailed sheep breeds (Bıyıkoğlu et al., 1977; Marai et al., 1987; Biçer, 1988; Gürsoy et al., 1992; Bingöl et al., 2002). Proportional yields of wholesale cuts of carcass and organs are presented in Table 3.

Table 3 Proportional yields (percentage \pm s.e.) of wholesale carcass cuts and organs relative to cold carcass weights of intact and docked male Karakaş lambs

\begin{tabular}{lcc}
\hline & \multicolumn{2}{c}{ Groups } \\
\cline { 2 - 3 } & Control & Docked \\
\hline Heart, lungs and liver* & $4.37 \pm 0.09$ & $4.35 \pm 0.09$ \\
Testes*** & $0.64 \pm 0.08$ & $0.68 \pm 0.06$ \\
Kidney & $0.67 \pm 0.04$ & $0.68 \pm 0.02$ \\
Kidney and pelvic fat & $0.41 \pm 0.03^{* *}$ & $0.84 \pm 0.10^{* *}$ \\
Internal fat*** & $0.26 \pm 0.04^{* *}$ & $0.78 \pm 0.14^{* *}$ \\
Tail & $13.7 \pm 1.16^{* *}$ & $6.1 \pm 0.52^{* *}$ \\
Legs & $30.0 \pm 2.46$ & $32.1 \pm 1.08$ \\
Back-loin & $15.6 \pm 0.28^{* *}$ & $17.9 \pm 0.46^{* *}$ \\
Shoulder & $5.54 \pm 0.24$ & $5.72 \pm 0.28$ \\
Neck & $7.34 \pm 0.24$ & $7.82 \pm 0.18$ \\
Fore-arms & $16.6 \pm 0.36$ & $16.8 \pm 0.22$ \\
Flank-chest & $10.1 \pm 0.20^{* *}$ & $13.3 \pm 0.32^{* *}$ \\
\hline Relative to slaughter weight & \\
$* *$ Within rows differences were statistically significant at $\mathrm{P}<0.01$ \\
$* * *$ Relative to warm carcass weight \\
\multicolumn{2}{|}{}
\end{tabular}

There were significant differences in proportional yields of kidney and pelvic fat, internal fat, tail, back-loin and flank-chest between the two groups. Except for the tail, these measures were higher $(\mathrm{P}<0.01)$ in the docked than in the control group. An increase in fat around internal organs in response to docking and a decrease in the tail fat portion have been reported by Bıyıkoğlu et al. (1977), Cengiz \& Arık (1994) and Bingöl et al. (2002). The results of the present study are in agreement with the report by Cengiz \& Arık (1994) that docking reduced the amount of total fat in a lamb's body. Muscle, bone and fat components of 
the carcasses assessed from the $6^{\text {th }}$ and $12^{\text {th }}$ rib cut of control and docked Karakas lambs are presented in Table 4.

Table 4 The proportion $(\% \pm$ s.e. $)$ of muscle, bone and fat in the carcasses of intact and docked lambs, assessed in the $6^{\text {th }}-12^{\text {th }}$ rib area

\begin{tabular}{lcc}
\hline & \multicolumn{2}{c}{ Groups } \\
\cline { 2 - 3 } & Control & Docked \\
$\%$ & $44.8 \pm 1.33$ & $40.9 \pm 1.65$ \\
\hline Muscle & $26.3 \pm 1.00^{*}$ & $23.1 \pm 1.15^{*}$ \\
Bone & $9.1 \pm 1.11^{* *}$ & $16.2 \pm 1.05^{* *}$ \\
Subcutaneous fat & $3.28 \pm 0.46^{*}$ & $6.24 \pm 1.29 *$ \\
Intramuscular fat & \\
$*$ Within rows differences were significant at $\mathrm{P}<0.05$ & \\
$* *$ Within rows differences were significant at $\mathrm{P}<0.01$ &
\end{tabular}

Estimated from the $6^{\text {th }}-12^{\text {th }}$ rib cut, the docked lambs contained a lower proportion of bone $(\mathrm{P}<0.05)$ and a higher proportion of subcutaneous fat $(\mathrm{P}<0.01)$ and intramuscular fat $(\mathrm{P}<0.05)$ than the intact lambs. Since intramuscular fat increases the taste of meat, consumers prefer carcasses with the fat distributed between the meat fibres. These results indicated that docking seems to be beneficial in complying with consumers' demands, though the docked group had a lower $(\mathrm{P}>0.05)$ percentage of muscle than the control group. Similar results have been reported in Akkaraman lambs (Cengiz \& Arrk, 1994). Fat tail docking increased the percentage of intramuscular and subcutaneous fat in the carcass, and thus the total fat content of the lamb carcass, in agreement with Alkass et al. (1985), Biçer (1988), Biçer et al. (1992) and Cengiz \& Arık (1994). These results are also in agreement with those of Demiruren et al. (1972), Gürsoy et al. (1992) and Cengiz \& Arrk (1994) who reported that carcasses of docked lambs tended to have a higher proportion of intramuscular and subcutaneous fat deposits and less tail fat than intact lambs and are thus more desirable to consumers. However, Biyıkoğlu et al. (1977) noted that docking age might affect the lean content of the carcass. In the present study animals that were docked at one day of age, produced desirable carcass characteristics, in agreement with results reported by Alkass et al. (1985), Biçer (1988), Biçer et al. (1992), Cengiz \& Arık (1994) and Bingöl et al. (2002).

Despite the fact that different studies referring to the docking of fat-tailed lambs reported inconsistent effects on growth rate, the majority found that docking in lambs improves the live weight gain, feed efficiency and carcass quality. In this study, growth rates and carcass characteristics of Karakaş lambs were more desirable in docked lambs than in undocked lambs.

\section{Conclusions}

The commercial value of lamb carcasses is determined by the proportion of the fat and muscle and by weight. Docked animals produced more desirable carcasses than untreated animals, indicating that docking of fat-tailed sheep breeds may be an effective way to improve growth rates and desirable carcass characteristics. All the fat was relocated in the carcass rather than in the tail of docked lambs. A carcass with better distribution of fat into the muscle fibres is preferred by the consumer. Docking of native fat-tailed breeds of Eastern Anatolia may be suggested to improve growth performance and desirable carcass characteristics.

\section{Acknowledgements}

The Research Fund of Yüzüncü Yıl University supported this investigation financially.

\section{References}

Alkass, J.E., Rashid, N.H., Ali İshak, M. \& Talib H., 1985. The combined effects of docking and castration on growth rate and carcass characteristics of Awassi lambs. Wld Rev. Anim.Prod. 21, 49-52.

Anonymous, 2000. Statistical Yearbook of Turkey. State Institute of Statistics. Prime Ministry Republic of Turkey, Ankara.

Aygün, T., Demirel, M., Gökdal, Ö., Çelikyürek, H. \& Kor, A., 1998. Farklı sürelerde sütten kesilen ve meraya ek olarak kesif yemle beslenen Karakaş kuzularının besi gücü ve karkas özellikleri 
${ }^{\odot}$ South African Society for Animal Science

(Fattening performance and carcass characteristics of Karakas lambs weaned at different ages and fattened concentrate in addition to the natural pasture). Yüzüncü Yıl Üniv. Zir. Fak., Tarım Bilimleri Derg. 8, 9-16.

Bıyıkoğlu, K., Çakır, A. \& Yazgan, O., 1977. Doğu Anadolu'da Morkaraman koyunlarında kuyruk kesiminin gelişmeye, et verimine ve kalitesine etkileri (The effects of docking of Morkaramans on growth, meat yield and quality in Eastern Anatolia). Atatürk Üniv. Yay. 495, Zir.Fak.Yay. 232, Araştırma Serisi. 149, 40 pp.

Biçer, O., 1988. İvesi koyunlarının besi gücü ve karkas özellikleri üzerinde bir araştırma (An investigation on fattening performance and carcass traits of Awassi lambs). Çukurova Üniv. Fen Bil. Enst. Zootekni ABD, Doktora Tezi (Ph.D. Thesis). 128 pp., Adana, Turkey.

Biçer, O., Pekel, E. \& Güney, O., 1992. Effects of docking on growth performance and carcass characteristics of fat-tailed Awassi ram lambs. Small Rumin. Res. 8, 353-357.

Bingöl, M., Aygün, T., Gökdal, Ö. \& Yılmaz, A., 2002. Norduz kuzularında kuyruk kesiminin besi gücü ve karkas özellikleri üzerine etkileri (The effects of docking on fattening ferformance and carcass characteristics of male Norduz lambs). The research report. (Research Fund of Yüzüncü Y1l University).

Cengiz, F. \& Arık, İ.Z., 1994. Akkaraman kuzularında kuyruk kesiminin besi gücü ve karkas özellikleri üzerine etkileri (Effects of tail docking on fattening performance and carcass characteristics of Akkaraman lambs). Scientific Research and Studies Vol. 750, Publ. no.1356, Publication of Agric. Faculty, Ankara University.

Cengiz, F., Ertuğrul, M. \& Eliçin, A., 1989. Akkaraman ve Border Leicester x Akkaraman $\left(F_{1}\right)$ melezi erkek kuzularında besi gücü ve karkas özellikleri (Fattening performance and carcass characteristics in male lambs of Akkaraman and crossbred $\left(F_{1}\right)$ Border Leicester $x$ Akkaraman). Scientific Research and Studies Vol. 612, Publ. no.1121, Publication of Agric. Faculty, Ankara University.

Cengiz, F., Gökdal, Ö., Ülker, H., Karakuş, F. \& Temur, C., 2002. Possibilities of using Ile de France x Akkaraman crossbred $\left(\mathrm{G}_{1}\right)$ genotype in improving meat yield characteristics of Karakaş sheep. The research report. TÜBİTAK-TOGTAG-TARP, Project No. 2427.

Colomer-Rocher, F., Morand-Fehr, P. ve Kirton, A.H., 1987. Standard methods and procedures for goat carcass evaluation jointing and tissue separation. Livest. Prod. Sci. 17, 149-157.

Demirulus, H. \& Karaca, O., 1994. Karakaş kuzularının köylü şartlarında kimi gelişme özellikleri (Some growth characteristics of Karakaş lambs under rural farm conditions). Yüzüncü Y1l Üniv., Zir. Fak. Derg. 4, 75-85.

Demiruren, A.S., Behesthi, R.D., Salimi, H., Saleh, B.A. \& Djaferi, A., 1972. Comparison of the reproductive and productive capacities of sheep of the Kellauki, Kizil, Bakhtiari and Baluchi breeds in Iran. Anim. Breed. Abst. 40, 78.

Eliçin, A., Ertuğrul, M., Cengiz, F., Aşkın, Y. \& Dellal, G., 1989. Karayaka ve Border Leicester x Karayaka $\left(\mathrm{F}_{1}\right)$ erkek kuzularda besi gücü ve karkas özellikleri (Fattening performance and carcass characteristics in male lambs of Karayaka and crossbred $\left(F_{l}\right)$ Border Leicester $x$ Karayaka). Scientific Research and Studies, Vol. 613, Publ. no.1123, Publication of the Agric. Faculty, Ankara University.

Ertuğrul, M., Cengiz, F. \& Eliçin, A., 1989. Akkaraman ve Dorset Down x Akkaraman melezi $\left(\mathrm{F}_{1}\right)$ kuzularda besi gücü ve karkas özellikleri (Fattening performance and carcass characteristics of Akkaraman and crossbred $\left(F_{1}\right)$ Dorset Down $x$ Akkaraman). Scientific Research and Studies, Vol. 608, Publ. no.1117, Publication of Agric. Faculty, Ankara University.

Gökdal Ö., 1998. Karakaş koyunlarının süt ve döl verimleri ile dışyapı ve büyüme-gelişme özellikleri (The milk yield, reproductive performance, some body measurements and growth characteristics of Karakaş sheep). Yüzüncü Y11 Üniv., Fen Bil. Enst., Doktora tezi (Ph.D. Thesis), 107 pp., Van., Turkey.

Gökdal Ö., Ülker, H., Temur, C., Oto, M.M. \& Budağ, C., 1999. Köylü koşullarında yetiştirilen Karakaş kuzularının sütten kesim dönemine kadarki büyüme-gelişme özellikleri ile vücut ölçüleri (Growth traits and body measurements of Karakaş lambs until weaning in rural farm conditions). Yüzüncü Y1l Üniv. Zir. Fak. Tarım Bilimleri Derg. 9, 1, 41-49.

Gökdal, Ö., Ülker, H.. Oto, M., Temur, C. \& Budağ, C., 2000. Köylü koşullarında yetiştirilen Karakaş koyunlarının çeşitli verim özellikleri ve vücut ölçüleri (Different production traits and body 
measurements of Karakaş sheep in rural farm conditions). Yüzüncü Yıl Üniv. Zir. Fak. Tarım Bilimleri Derg. 10, 1, 103-111.

Gürsoy, O. \& Özcan, L., 1982. Kuyruk köreltme ve kastrasyonun İvesi kuzularının gelişmesine etkileri (Effects of docking and castration on growth performance of Awassi lambs). Yearbook, Vol. 13, 2. Çukurova Univ., Faculty of Agric. 49-63.

Gürsoy, O., Özcan, L. \& ve Pekel, E., 1992. Effects of castration and docking on carcass characteristics of Awassi lambs. Çukurova Üniv. Zir.Fak.Derg. 4, 4, 88-95.

Karakuş, F., 2000. 70 gün süre ile entansif besiye alınan Norduz kuzularında besi gücü ve karkas özellikleri (Fattening performance and carcass characteristics of Norduz lambs fed intensively for 70 days). Yüzüncü Y1l Üniv. Fen Bil. Enst. Zootekni ABD, Yüksek Lisans tezi (MSc thesis), 42 pp., Van, Turkey.

Karakuş, F. \& Cengiz, F., 2001. Yağlı kuyruklu koyunlarda kuyruk kesiminin besi gücü ve karkas özelliklerine etkileri (Effects of docking on fattening performance and carcass characteristics of fattailed sheep). GAP II. Agricultural Cong., October 24-26, Şanlıurfa, Turkey.

Karaca, O., Altın, T. \& Okut, H., 1996. Köylü işletmelerde Karakaş koyunlarının canlı ağırlık değişimlerine ilişkin kimi parametre tahminleri (Some parameters estimation on the live weights changes of Karakaş ewes in the rural farms). Yüzüncü Yıl Üniv., Zir. Fak. Derg. 6, 3, 59-72.

Karaca, O., Vanlı, Y., Kaygısız, A., Altın, T. \& Demirel, M., 1991. Karakaş erkek kuzularının besi ve karkas özellikleri (Fattening performance and carcass characteristics of Karakaş sheep). Yüzüncü Y11 Üniv., Zir. Fak. Derg., 1/1, 147-164.

Marai, I.F.M., Nowar, M.S. \& Bahgat, L.B., 1987. Effect of docking and shearing on growth and carcass traits of fat tailed Ossimi sheep. J. Agric. Sci., Camb. 109, 513-518.

More O'Ferral, G.J. \& Timon, V.M., 1977. A comparison of eight sire breeds for lamb production. II. Lamb carcass composition. Ir. J. Agric. Res. 16, 277-284.

Negussie, E., Rottmann, O.J., Pirchner, F. \& Rege, J.E.O., 2003. Patterns of growth and partitioning of fat depots in tropical fat-tailed Menz and Horro sheep breeds. Meat Sci. 64, 491-498.

O’Donovan, P.B., Ghadaki, M.B., Behesti, R.D., Saleh, B.A. \& Rollinson, D.H.L., 1973. Performance and carcass composition of docked and control fat-tailed Kellakui lambs. Anim. Prod. 16, 67-76.

Peers, A., Mellor, D.J., Wintour, E.M. \& ve Dodic, M., 2002. Blood pressure, hearth rate, hormonal and other acute responses to rubber-ring castration and tail docking of lambs. N. Z. Vet. J. 50, 56-62.

Pollard, J.C., Roos, V. \& Littlejohn, R.P., 2001. Effects of an oral dose of acetyl salicylate at tail docking on the behaviour of lambs aged three to six weeks. Appl. Anim. Behav. Sci. 71, 29-42.

SAS, 1998. PC SAS user's Guide. Statistics SAS Inst. Carry. North Carolina, USA.

Ülker, H., Gökdal, Ö., Temur, C., Budağ, C., Oto, M., De Avila, D.M. \& Reeves, J.J., 2002. The effects of immunization against LHRH using recombinant LHRH fusion proteins on body growth and carcass characteristics in ram lambs. Small Rumin. Res. 45, 273-278. 